\title{
Biology of Infection and Disease Pathogenesis to Guide RSV Vaccine Development
}

OPEN ACCESS

Edited by:

Shokrollah Elahi,

University of Alberta, Canada

Reviewed by:

Sang-Moo Kang Georgia State University,

United States

Cecilia Johansson, Imperial College London, United Kingdom

*Correspondence:

Larry J. Anderson larry.anderson@emory.edu

Specialty section: This article was submitted to Viral Immunology,

a section of the journal

Frontiers in Immunology

Received: 08 April 2019 Accepted: 04 July 2019 Published: 25 July 2019

Citation:

Boyoglu-Barnum S, Chirkova T and Anderson LJ (2019) Biology of Infection and Disease Pathogenesis to Guide RSV Vaccine Development. Front. Immunol. 10:1675 doi: 10.3389/fimmu.2019.01675

\author{
Seyhan Boyoglu-Barnum ${ }^{1}$, Tatiana Chirkova ${ }^{2}$ and Larry J. Anderson ${ }^{2 *}$ \\ ${ }^{1}$ Vaccine Research Center, National Institutes of Health, Bethesda, MD, United States, ${ }^{2}$ Department of Pediatrics, Emory \\ University and Children's Healthcare of Atlanta, Atlanta, GA, United States
}

Respiratory syncytial virus (RSV) is a leading cause of severe lower respiratory tract disease in young children and a substantial contributor to respiratory tract disease throughout life and as such a high priority for vaccine development. However, after nearly 60 years of research no vaccine is yet available. The challenges to developing an RSV vaccine include the young age, 2-4 months of age, for the peak of disease, the enhanced RSV disease associated with the first RSV vaccine, formalin-inactivated RSV with an alum adjuvant (FI-RSV), and difficulty achieving protection as illustrated by repeat infections with disease that occur throughout life. Understanding the biology of infection and disease pathogenesis has and will continue to guide vaccine development. In this paper, we review the roles that RSV proteins play in the biology of infection and disease pathogenesis and the corresponding contribution to live attenuated and subunit RSV vaccines. Each of RSV's 11 proteins are in the design of one or more vaccines. The G protein's contribution to disease pathogenesis through altering host immune responses as well as its role in the biology of infection suggest it can make a unique contribution to an RSV vaccine, both live attenuated and subunit vaccines. One of G's potential unique contributions to a vaccine is the potential for anti-G immunity to have an antiinflammatory effect independent of virus replication. Though an anti-viral effect is essential to an effective RSV vaccine, it is important to remember that the goal of a vaccine is to prevent disease. Thus, other effects of the infection, such as G's alteration of the host immune response may provide opportunities to induce responses that block this effect and improve an RSV vaccine. Keeping in mind the goal of a vaccine is to prevent disease and not virus replication may help identify new strategies for other vaccine challenges, such as improving influenza vaccines and developing HIV vaccines.

Keywords: pathogenesis, RSV (respiratory syncytial virus), vaccine development, biology of infection, protective immunity

\section{BACKGROUND}

Respiratory syncytial virus (RSV) is estimated to cause 3.4 million hospitalizations and 95,000-150,000 deaths globally and up to 175,000 hospitalizations in the United States in children $<5$ years of age each year $(1,2)$. It is also estimated to cause 14,000 deaths each year in adults in the United States (3). Its disease burden has made RSV a priority for vaccine development for over 50 years but no vaccine is yet available for any of groups targeted for an RSV vaccine including young 
children ( $\sim<6$ months of age), older children $(\sim 6$ months to 24 months of age), pregnant women, and elderly adults $(\sim>65$ years of age) $(4,5)$. The challenges to developing an RSV vaccine include: concern that a non-live virus vaccine in young children may predispose to enhanced RSV disease (ERD) in RSV-infected young children who earlier received a formalin-inactivated RSV plus alum vaccine; difficulty in inducing and assessing protective immunity; cost of clinical vaccine trials; and the young age, 24 months of age, for peak of disease. The first RSV vaccine, formalin-inactivated RSV with alum adjuvant (FI-RSV), given to young, likely RSV naïve, but not older, RSV primed children, led to enhanced RSV disease (ERD) with later infection, i.e., a high rate of hospitalization and two deaths (6-9). This experience raised concern that any non-live virus vaccine may induce an aberrant immune response that predisposes to ERD in young children and a focus on live attenuated RSV or virus vector vaccines for this target population. Since ERD is not a concern for RSV-primed older children and adults and live attenuated RSV replicates poorly in primed persons, subunit vaccines are under development for older children and adults. The difficulty in inducing protective immunity is highlighted by repeat infections and disease throughout life $(3,10)$.

The fact that prior infection and high titers of neutralizing antibodies, e.g., maternally derived antibodies or from an earlier infection, are associated with some protection suggest that a vaccine should be achievable (11-17). In addition, immune globulin with a high RSV neutralizing antibody titer and a neutralizing monoclonal antibody are effective in preventing serious disease in high-risk young infants $(18,19)$.

The past failures, however, suggest that novel vaccines may be required for success. In considering novel vaccines, it is useful to remember that the goal of a vaccine is to prevent disease caused by the infection. Though obviously important to an effective vaccine, a singular focus on induction of neutralizing antibodies or preventing virus replication, may lead to missing other, important effects of a vaccine. For example, if a vaccine does not induce sterilizing immunity, as is likely for RSV, other effects such as virus-induced inflammation become relevant. The pathogenesis of RSV disease, reviewed elsewhere $(20,21)$, is the foundation for designing a vaccine that addresses disease pathogenesis. The prominence of wheezing as a manifestation of infection (10) with its similarity to asthma and the association between mucus production and disease severity (22) suggest a prominent role of host inflammatory responses in disease pathogenesis. Blocking such effects could be important to a successful vaccine.

The role of RSV's proteins in biology of infection and disease pathogenesis provides clues to their potential contribution to a vaccine. RSV has 10 genes that encode for 11 proteins (23). RSV has two major antigenic groups of strains, A and B, and multiple genotypes within the two groups (24-27). Though only two RSV proteins induce in vitro neutralizing antibodies, F and G (28), as illustrated in Table 1, all RSV proteins have played a role in design of one or more vaccines. The type of vaccine under development varies among the target populations. Live attenuated or virusvector subunit vaccines are under development for infants and young children and non-live or virus-vector subunit vaccines for older children and adults.

\section{LIVE VIRUS VACCINES}

A live attenuated RSV vaccine needs to both have mutations that attenuate virus replication for safety while maintaining sufficient replication to maintain immunogenicity. The first attenuated vaccines were generated by chemical mutagenesis and low temperature passage. Subsequently, reverse genetics has identified specific mutations associated with temperature sensitivity and attenuation $(30,31)$. A set of five mutations, one in the $\mathrm{N}$, two in the $\mathrm{F}$, and two in the $\mathrm{L}$ protein genes, are associated with attenuation in primates and designated "cp" for cold passage. Six additional mutations, 5 in $\mathrm{L}$ and 1 in the gene-start transcription signal for M2, contribute independently to temperature sensitivity and attenuation. Five RSV genes, i.e., NS1, NS2, SH, G, and M2-2, can be deleted and virus recovered. All viruses are attenuated in animals. Live attenuated RSV candidate vaccines with deletions of NS2, G, or M2-2 are in clinical trials (32). A live attenuated RSV candidate vaccine with the $5 \mathrm{cp}$ mutations, two other attenuating mutations, and deletion of the $\mathrm{SH}$ gene was also in a clinical trial $(33,34)$.

A virus vector vaccine's safety is likely not dependent on the RSV antigen present but the vector. Since the virus vectors present antigen to the immune system similar to the way that live RSV does, they are likely safe from ERD risk. A parainfluenza virus that expressed the RSV F protein did not led to ERD in RSV naïve children (35).

Codon pair de-optimization is another way to attenuate RSV and different combinations of RSV proteins including NS1 and NS2; NS1, NS2, N, P, M, and SH; G and F; L; or all proteins except M2-1 and M2-2 have been codon de-optimized to attenuate the virus $(36,37)$. With codon pair de-optimization, the level of attenuation can be fine-tuned by varying levels of protein production and makes it possible to attenuate through changes to any protein without relying on specific attenuating mutations or gene deletion.

Several live attenuated RSV vaccines show promise in early clinical trials (38). It is yet uncertain if they will achieve the balance between safety and immunogenicity needed for the young child. Maternal vaccination, or longer lasting immune prophylaxis, followed by vaccination at 4-6 months of age should make safety easier to achieve. A safe virus vector is another possible way to protect young children.

\section{SUBUNIT VACCINES}

With the exception of virus-vector subunit vaccines, subunit vaccines are under development for RSV-primed older children and adults. Virus vector vaccines are under development for both. The goal for a subunit vaccine is to safely, induce a more effective immune response than natural infection. One or both of RSV proteins that induce neutralizing antibodies ( $F$ and $G$ ) are likely required for an effective subunit vaccine. Proteins 
TABLE 1 | RSV proteins in live attenuated or subunit vaccines.

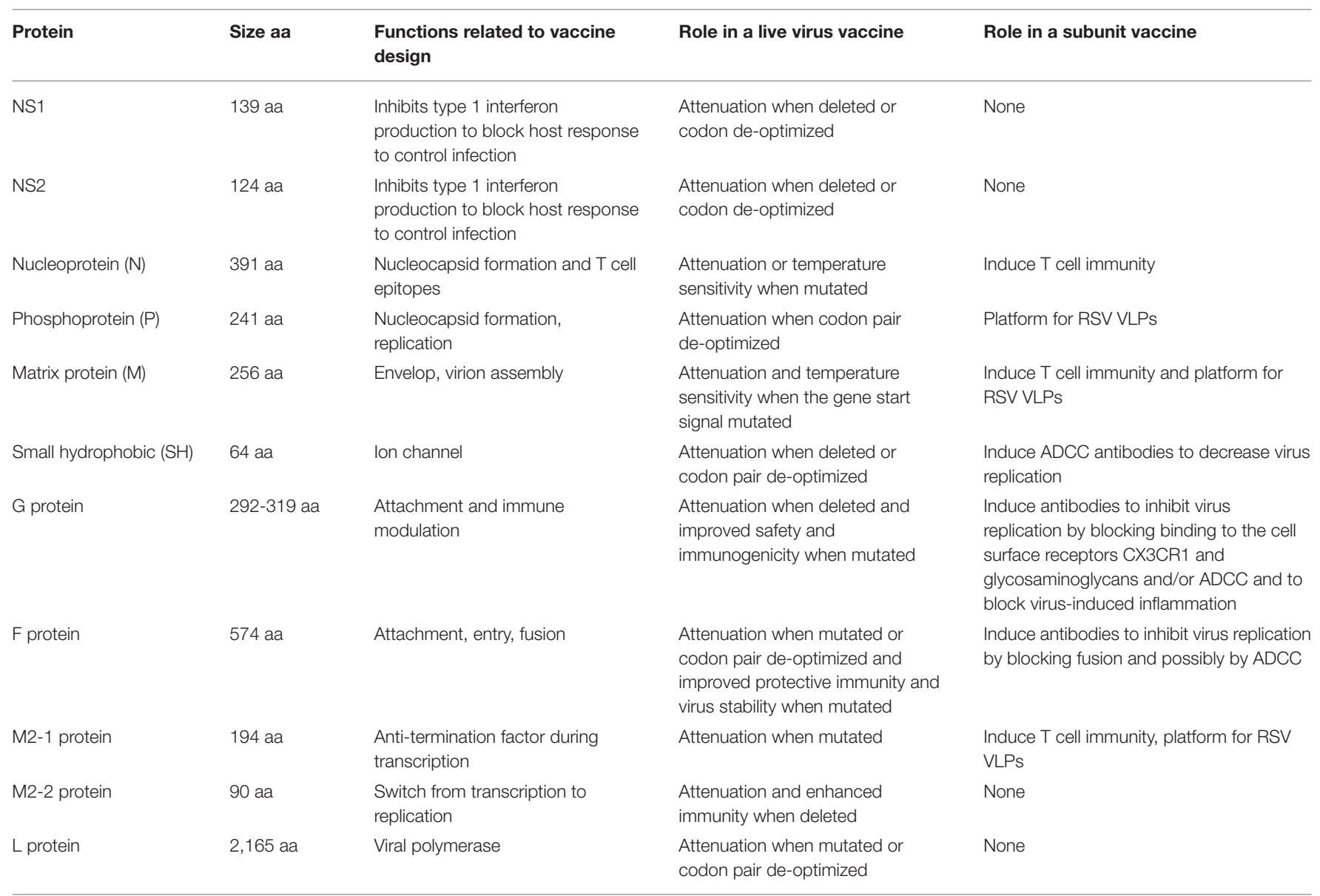

Adapted with permission from Anderson (29).

that induce $\mathrm{T}$ cell immunity (N, M2-1, and other proteins) or antibody dependent cellular cytotoxic antibodies (ADCC) including the $\mathrm{F}, \mathrm{G}$, and $\mathrm{SH}$ proteins are incorporated into subunit vaccines (Table 1). Co-expression of the $\mathrm{M}$ protein and $\mathrm{P}$ proteins produces RSV virus-like-particle (VLPs) vaccine platform. A number of subunit vaccines, some in a virus vectors, including F protein; G protein; SH protein; F plus G; or F, G, and other RSV proteins are under study in clinical trials $(4,32)$.

Several pre-fusion F subunit vaccines are in early clinical trials and expected to induce higher titers of neutralizing antibodies and be more effective than previous $F$ protein vaccines. Recently, two non-prefusion stabilized F protein vaccines were ineffective in elderly adults in phase II or III clinical trials (4). In a phase III maternal vaccination trial, one of these $\mathrm{F}$ protein vaccines did not significantly decrease medically significant RSV lower respiratory tract illness in infants (its primary endpoint) but did significantly decrease hospitalization in the infant (38), a result that suggests an $\mathrm{F}$ protein can be an effective maternal vaccine. An extended half-life, anti-F neutralizing monoclonal antibody is in phase II or III clinical trials and a promising alternative to vaccination to protect infants (39).

\section{FUNCTION AND ROLE OF RSV PROTEINS IN VACCINE DESIGN}

As noted above and outlined in Table 1, all RSV proteins are included in design of one or more vaccines. Understanding the role of RSV proteins in the biology of infection and disease pathogenesis helps determine if, and how, individual proteins might contribute to a vaccine.

Below we discuss each proteins function relative to vaccine design with an emphasis on the $F$ and $G$ proteins. $F$ and $G$ are most effective at inducing protective immunity and one or both likely needs to be included in a RSV vaccine. Though G is often not included in candidate vaccines, its role in disease pathogenesis suggest it might make important contributions to a vaccine.

\section{NS1 and NS2 Proteins}

NS1 is a 139 aa and NS2 is a 124 aa non-structural proteins, i.e., not incorporated into the virus but produced during transcription and replication. They both participate in virus replication and antagonize host innate responses designed to control infection (40-49). Deleting or codon de-optimizing 
he gene ability to alter host cell responses that control the infection that reduces virus replication and attenuates the virus $(36,37,50-55)$.

\section{N Protein}

The 391-amino acid $\mathrm{N}$ protein binds to and encapsidates the viral RNA generating an RNAse resistant nucleocapsid that is the template for transcription and replication of RSV genome (56, 57). $\mathrm{N}$ also inhibits host cell down regulation of cellular and viral protein production (58) and may impair dendritic cell and $\mathrm{T}$ cell interactions (59). It does not induce neutralizing antibodies but does induce $T$ cell responses that protect animals at 4 weeks post vaccination $(28,60,61)$. Given its role in virus replication, deoptimizing $\mathrm{N}$ gene codons should attenuate a live virus vaccine and its induction of $\mathrm{T}$ cell responses might contribute to efficacy of subunit vaccines.

\section{P Protein}

The $\mathrm{P}$ protein is a 214 aa protein that is part of the ribonucleoprotein complex (RNP) $(56,57)$. The $\mathrm{P}$ protein interacts with both the $\mathrm{N}$ and $\mathrm{L}$ proteins and is an essential cofactor for $\mathrm{L}$ function. $\mathrm{P}$ also interacts with the M2-1 protein (62). Since co-transfection of $\mathrm{P}$ and $\mathrm{M}$ proteins produces RSV VLPs (63), it could be used in a subunit RSV VLP vaccine. P's role in virus replication suggest that de-optimizing $\mathrm{P}$ gene codons should attenuate the virus (36).

\section{Protein}

The $\mathrm{M}$ protein is 256 aa and guides assembly, budding, and virion formation (64). It lines the inner surface of the viral envelop, helps determine the shape of virus particles, and, with $\mathrm{P}$, forms VLPs $(63,65-69)$. Since $M$ induces $T$ cell responses in vaccinated animals and memory $\mathrm{T}$ cells in humans after natural infection $(70,71)$, it might improve a subunit vaccines efficacy.

\section{SH Protein}

The SH, small hydrophobic protein is a 64-65 amino acid type II protein located on the surface of the virus. It forms a pentameric cation-selective ion channel, or a viroporin, and can activate NLRP3 inflammasome leading to IL-1b expression $(72,73)$. Deletion of the SH gene is often used to attenuate live RSV candidate vaccine strains (74). Codon pair de-optimization (CPD) $(36,75)$ might also attenuate the virus. Though SH does not induce neutralizing (76), an SH vaccine induces antibodydependent cell-mediated cytotoxicity (ADCC) antibodies and protection in animals $(77,78)$ and being studied in clinical trials $(4,32)$.

\section{G Protein}

The G protein is a class II protein of 292-319 amino acids (AA) long. The extracellular domain contains a variable, highly glycosylated domain and a central conserved domain (CCD$\mathrm{G})$ followed by a second variable, highly glycosylated domain. Within the CCD-G are 13 aa conserved among all strains (aa 164-176) and a CX3C chemokine motif (aa 182-186). Through the CX3C motif, G, like the one CX3C chemokine, fractalkine, binds to the chemokine receptor CX3CR1 (79). G, as does F, also binds to cell surface glycosaminoglycans (GAGs) through its heparin binding domains and GAGs are one receptor for RSV infection. In primary human airway epithelial cells, RSV also uses CX3CR1, through the CX3C motif in $\mathrm{G}$, as a receptor for infection (80-82). G binding to CX3CR1 can also induce fractalkine-like responses (79). CX3CR1 is expressed on the surface of many cell types, including neurons and microglia (83), smooth muscle (84), and various immune cells including monocytes, dendritic, NK, T, and B cells (85-87) and binding to it can induce a variety of downstream responses. In mice, the $\mathrm{G}$ protein/CX3CR1 interaction is associated with depressed respiratory rates (88), inhibition of migration of CX3CR1+ T cells to RSV-infected lungs (89), induction of aberrant pulmonary inflammation with RSV challenge after FI-RSV vaccination (90), increased pulmonary inflammation and mucous production and airway resistance during infection, and induction of Th2-type immune responses in the lung with infection (91). In In vitro studies, the G protein through its interaction with CX3CR1 dampens Type I IFN production by innate immune cells and Type 1 cytokine responses of memory T cells (92). Recently, the G-CX3CR1 interaction has been shown to induce IL-10 in neonatal regulatory B cells (nBreg) resulting in downregulation of Th1 cell responses (93).

The ability of the anti-G monoclonal antibody, 131-2G, to block these effects of $G(91,94-97)$ suggests a role for $G$ in vaccine design. As illustrated in Figure 1, immunity designed to block infection, if successful, will prevent disease. However, if only partially successful, as occurs with naturally acquired immunity, RSV will replicate and produce G leading to $G$ induced host immune/inflammatory responses that cause disease. Vaccine-induced anti-G antibodies can block G-induced disease and essentially have an anti-inflammatory effect that decreases disease. Interestingly, the anti-inflammatory effect of $131-2 \mathrm{G}$ is independent of its anti-viral effect, i.e., intact 131-2G has both an anti-viral effect and anti-inflammatory effect while 131-2G $\mathrm{F}\left(\mathrm{ab} \mathbf{b}^{\prime}\right) 2$ has no anti-viral effect but a similar anti-inflammatory effect $(95,96)$. Since CX3CR1 is an important receptor in primary human airway epithelial cells, likely in natural human infection, antibodies that block G's interaction with CX3CR1 should neutralize virus in humans by a mechanism different from F. Finally, studies in mice suggest that anti-G immunity, through passively administered 131-2G before RSV challenge or actively induced by a CCDG peptide vaccine given with FI-RSV, can block ERD in RSVchallenge of FI-RSV vaccinated mice $(98,99)$. These data suggest that including $G$, or a CCD-G containing peptide, in an RSV vaccine might decrease the risk of ERD in infants and young children.

Thus, $G$ in a subunit vaccine can induce antibodies that block binding to CX3CR1 that should enhance the antiviral activity of an $\mathrm{F}$ protein subunit vaccine and uniquely add an anti-inflammatory effect not present in an $\mathrm{F}$ only vaccine (Figure 1). In a live attenuated vaccine, mutating $G$ to block binding to CX3CR1, from studies in mice, should markedly decreased disease and maintain, or enhance, the vaccine-induced immunity (100). This mutation by blocking binding to CX3CR1 would also attenuate virus replication in humans. 


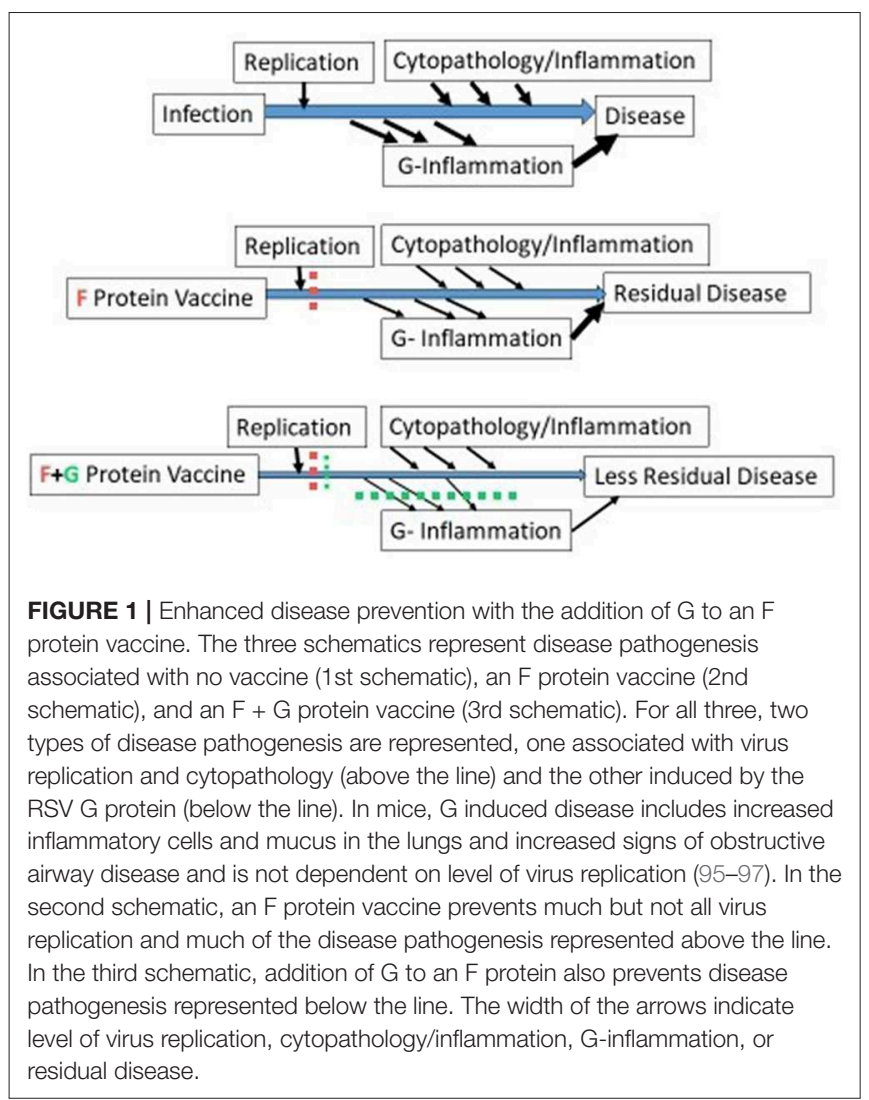

Thus, including G in RSV vaccine design could improve a vaccine through multiple mechanisms. A number of $G$, or $G$ peptides that include CCD-G, vaccines have been effective in preventing disease in animal studies (101-109). A G construct based on CCD-G will likely need to account for antigenic differences between groups $\mathrm{A}$ and $\mathrm{B}$ and not within the two groups.

\section{F Protein}

The F protein is a class I fusion protein of 574 amino acids (AA) long. It has two furin cleavages sites, at aa position 109 and the other at aa 136. Cleavage at these sites gives the $50 \mathrm{kDa}$ carboxy-terminal F1, the $20 \mathrm{kDa} \mathrm{N}$-terminal F2, and a 27 aa fragment. F1 and F2 form dimers and the F1-F2 dimers form trimmers $(110,111)$. The F protein is highly conserved among RSV strains with 25 AA differences between RSV subtypes A and $\mathrm{B}$ and induces neutralizing antibodies and protection in animals across the two groups $(110,112)$. F binds to glycosoaminoglycans (113), nucleolin (114), and EGFR (115) on the cell surface with GAGs and nucleolin presumed to be receptors for infection of cells. F binding to EGFR is associated with induction of IL-13 and mucin production.

The F protein mediates fusion of RSV with cellular membranes which is essential to infection and requires $\mathrm{F}$ to go from the metastable pre-fusion (pre-F) structure to a stable post-fusion (post-F) structure $(116,117)$. Many neutralizing epitopes on $\mathrm{F}$ are on the pre- and not post-fusion structure and most of the neutralizing antibodies in humans react against the pre- and not post-fusion form of F $(118,119)$. Pre-fusion stabilized $\mathrm{F}$ protein constructs have been developed and these F constructs, e.g., Ds-Cav1 and SC-TM, are highly effective at inducing neutralizing antibodies (120). Anti-F antibodies can also mediate antibody dependent cell-mediated cytotoxicity (ADCC) $(121,122)$ though it is unknown what role ADCC antibodies play in controlling natural infection. The initial two neutralizing antigenic sites identified on $\mathrm{F}$ have been expanded to at least five and more will likely be identified in the future $(24,123)$. Anti-antigenic site $\varnothing$ antibodies have high levels of neutralizing activity and are a high proportion of neutralizing antibodies in human serum specimens (118). Interesting, F proteins in some circulating strains have been shown to have increased stability of pre-fusion $\mathrm{F}$, increased virus temperature stability, induce mucus and airway resistance in mice, and bind to $\operatorname{EGFR}(115,124,125)$.

Stabilization of pre-fusion F in subunit vaccines substantially increases the neutralizing antibody response in animals and is a promising development in design of RSV subunit vaccines. In a live virus vaccine, mutations in $\mathrm{F}$ that increase prefusion stability and temperature stability should be advantageous. Mutations at other sites in $\mathrm{F}$ have been associated with virus attenuation. It is possible that mutations that block $\mathrm{F}$ binding to EGFR will attenuate disease and improve a live attenuated RSV vaccine.

The $\mathrm{F}$ protein's essential role in infection through fusion suggest it is key to protection for both subunit and live virus vaccines.

\section{M2-1 and M2-2 Proteins}

The internal viral matrix protein M2 is unique to the family Pneumoviridae, plays a significant role in virus assembly (66), and contains two overlapping translational open reading frames, one for M2-1, a 194 aa protein, and one for M2-2, a 83-90aa protein (126).

The M2-1 protein functions as an intragenic transcription anti-termination factor allowing the synthesis of complete RNA (127-129) and link the RNA/nucleocapsid with the M protein just inside the virus surface $(67,130)$. M2-1 can induce short term, T cell based RSV immunity $(28,70,131)$ and could be included in a subunit vaccine to enhance induction of $\mathrm{T}$ cell immunity.

The M2-2 protein facilitates the shift from gene transcription to production of viral RNA and infectious virus $(126,132)$. Deletion of M2-2 results in a decrease genome replication and increase in gene transcription and protein production resulting in both attenuation and increased immunogenicity. M2-2 deletion viruses are being evaluated in a phase 1 clinical trials $(34,133)$.

\section{Protein}

The $\mathrm{L}$ protein is a large, 2,165-amino acid, protein that mediates transcription and replication of RSV RNA and capping and methylation of mRNA $(56,57,134)$. The active form of $\mathrm{L}$ is a 
heterodimer of the $\mathrm{L}$ and $\mathrm{P}$ proteins with $\mathrm{P}$ essential to L's catalytic activity. Given its central role in transcription and replication it is not surprising that attenuating mutations, and likely codon pair de-optimization of L, attenuate live RSV (30, 31).

\section{COMMENT}

Though a number of candidate RSV vaccines are under development and some promising candidate vaccines have moved into clinical trials, past failures suggest that we should continue look for better candidate vaccines. Though the composition of a successful RSV vaccine remains uncertain, it likely will need to induce both antibody and Th1 biased $\mathrm{T}$ cell memory responses. It is, also, useful to remember that the goal is to prevent disease and not just to control infection. For example, tetanus and diphtheria toxoid vaccines prevent the disease and not pathogen growth. The RSV G protein has the potential to enhance a vaccine by not only helping to control infection but independently decreasing disease by controlling virus-induced inflammation. Virus protein-specific contributions to biology of infection and disease pathogenesis might also suggest ways to

\section{REFERENCES}

1. Shi T, McAllister DA, O'Brien KL, Simoes EAF, Madhi SA, Gessner BD, et al. Global, regional, and national disease burden estimates of acute lower respiratory infections due to respiratory syncytial virus in young children in 2015: a systematic review and modelling study. Lancet. (2017) 390:946-58. doi: 10.1016/S0140-6736(17)30938-8

2. Stockman LJ, Curns AT, Anderson LJ, Fischer-Langley G. Respiratory syncytial virus-associated hospitalizations among infants and young children in the United States, 1997-2006. Pediatr Infect Dis J. (2012) 31:5-9. doi: 10.1097/INF.0b013e31822e68e6

3. Falsey AR, Hennessey PA, Formica MA, Cox C, Walsh EE. Respiratory syncytial virus infection in elderly and high-risk adults. N Engl J Med. (2005) 352:1749-59. doi: 10.1056/NEJMoa043951

4. Mazur NI, Higgins D, Nunes MC, Melero JA, Langedijk AC, Horsley N, et al. The respiratory syncytial virus vaccine landscape: lessons from the graveyard and promising candidates. Lancet Infect Dis. (2018) 18:e295-e311. doi: 10.1016/S1473-3099(18)30292-5

5. Anderson LJ, Dormitzer PR, Nokes DJ, Rappuoli R, Roca A, Graham BS. Strategic priorities for respiratory syncytial virus (RSV) vaccine development. Vaccine. (2013) 31(Suppl. 2):B209-15. doi: 10.1016/j.vaccine.2012.11.106

6. Chin J, Magoffin RL, Shearer LA, Schieble JH, Lennette EH. Field evaluation of a respiratory syncytial virus vaccine and a trivalent parainfluenza virus vaccine in a pediatric population. Am Epidemiol J. (1969) 89:449-63. doi: 10.1093/oxfordjournals.aje.a120957

7. Kim HW, Canchola JG, Brandt CD, Pyles G, Chanock RM, Jensen K, et al. Respiratory syncytial virus disease in infants despite prior administration of antigenic inactivated vaccine. Am. Epidemiol J. (1969) 89:422-34. doi: 10.1093/oxfordjournals.aje.a120955

8. Fulginiti VA, Eller JJ, Sieber OF, Joyner JW, Minamitani M, Meiklejohn G. Respiratory virus immunization: I. A field of two inactivated respiratory virus vaccines; an aqueous trivalent parainfluenza virus vaccine and an alum-precipitated respiratory syncytial virus vaccine. Am Epidemiol J. (1969) 89:435-48. doi: 10.1093/oxfordjournals.aje.a12 0956

9. Kapikian AZ, Mitchell RH, Chanock RM, Shvedoff RA, Stewart CE. An epidemiologic study of altered clinical reactivity to respiratory syncytial (RS) virus infection in children previously vaccinated with decrease disease for other vaccine challenges such as improving influenza vaccines and developing HIV vaccines.

\section{AUTHOR'S NOTE}

Respiratory syncytial virus is a high priority for vaccine development but, despite nearly 60 years of research no vaccine is yet available. Understanding the biology of infection and pathogenesis of disease has and will continue to be key to developing new vaccine strategies to finally achieve a successful vaccine. New vaccines are being developed and their safety and efficacy will ultimately be determined by clinical trials in the target population. Given past failures it is important to continue to pursue better candidate vaccines. In developing new vaccines, it is useful to remember that the goal of a vaccine is to prevent disease and not, though essential to an effective vaccine, virus replication.

\section{AUTHOR CONTRIBUTIONS}

All authors listed have made a substantial, direct and intellectual contribution to the work, and approved it for publication.

an inactivated RS virus vaccine. Am Epidemiol J. (1969) 89:405-21. doi: 10.1093/oxfordjournals.aje.a120954

10. Hall CB, Weinberg GA, Iwane MK, Blumkin AK, Edwards KM, Staat MA, et al. The burden of respiratory syncytial virus infection in young children. N Engl J Med. (2009) 360:588-98. doi: 10.1056/ NEJMoa0804877

11. Lamprecht CL, Krause HE, Mufson MA. Role of maternal antibody in pneumonia and bronchiolitis due to respiratory syncytial virus. J Infect Dis. (1981) 134:211-7. doi: 10.1093/infdis/ 134.3.211

12. Ogilvie MM, Vathenen AS, Radford M, Codd J, Key S. Maternal antibody and respiratory syncytial virus infection in infancy. J Med Virol. (1981) 7:263-71. doi: 10.1002/jmv.1890070403

13. Glezen WP, Paredes A, Allison JE, Taber LH, Frank AL. Risk of respiratory syncytial virus infection for infants from low-income families in relationship to age, sex, ethnic group, and maternal antibody level. Pediatr J. (1981) 98:708-15. doi: 10.1016/S0022-3476(81)80829-3

14. Stensballe LG, Ravn H, Kristensen K, Agerskov K, Meakins T, Aaby P, et al. Respiratory syncytial virus neutralizing antibodies in cord blood, respiratory syncytial virus hospitalization, and recurrent wheeze. J Allergy Clin Immunol. (2009) 123:398-403. doi: 10.1016/j.jaci.2008.10.043

15. Walsh EE, Wang L, Falsey AR, Qiu X, Corbett A, Holden-Wiltse $\mathrm{J}$, et al. Virus-specific antibody, viral load, and disease severity in respiratory syncytial virus infection. J Infect Dis. (2018) 218:208-17. doi: 10.1093/infdis/jiy106

16. Walsh EE, Falsey AR. Humoral and mucosal immunity in protection from natural respiratory syncytial virus infection in adults. J Infect Dis. (2004) 190:373-8. doi: 10.1086/421524

17. Piedra PA, Jewell AM, Cron SG, Atmar RL, Glezen WP. Correlates of immunity to respiratory syncytial virus (RSV) associatedhospitalization: establishment of minimum protective threshold levels of serum neutralizing antibodies. Vaccine. (2003) 21:3479-82. doi: 10.1016/S0264-410X(03)00355-4

18. The IMpact-RSV Study Group. Palivizumab, a humanized respiratory syncytial virus monoclonal antibody, reduces hospitalization from respiratory syncytial virus infection in high-risk infants. Pediatrics. (1998) 102:531-7. doi: 10.1542/peds.102.3.531

19. Groothuis JR, Simoes EAF, Levin MJ, Hall CB, Long CE, Rodriguez WJ, et al. Prophylactic administration of respiratory syncytial virus immune globulin 
in high-risk infants and young children. N Engl Med J. (1993) 329:1524-30. doi: 10.1056/NEJM199311183292102

20. Schmidt ME, Varga SM. Modulation of the host immune response by respiratory syncytial virus proteins. J Microbiol. (2017) 55:161-71. doi: 10.1007/s12275-017-7045-8

21. Openshaw PJM, Chiu C, Culley FJ, Johansson C. Protective and harmful immunity to RSV infection. Annu Rev Immunol. (2017) 35:501-32. doi: 10.1146/annurev-immunol-051116-052206

22. Rajan D, O'Keefe EL, Travers C, McCracken C, Geoghegan S, Caballero MT, et al. MUC5AC levels associated with respiratory syncytial virus disease severity. Clin Infect Dis. (2018) 67:1441-4. doi: 10.1093/cid/ciy340

23. Collins PL, Melero JA. Progress in understanding and controlling respiratory syncytial virus: still crazy after all these years. Virus Res. (2011) 162:80-99. doi: 10.1016/j.virusres.2011.09.020

24. Anderson LJ, Hierholzer JC, Tsou C, Hendry RM, Fernie BF, Stone $\mathrm{Y}$, et al. Antigenic characterization of respiratory syncytial virus strains with monoclonal antibodies. J Infect Dis. (1985) 151:626-33. doi: 10.1093/infdis/151.4.626

25. Mufson MA, Orvell C, Rafnar B, Norrby E. Two distinct subtypes of human respiratory syncytial virus. J Gen Virol. (1985) 66:2111-24. doi: 10.1099/0022-1317-66-10-2111

26. Peret TCT, Hall CB, Hammond GW, Piedra PA, Storch GA, Sullender WM, et al. Circulation patterns of group A and B human respiratory synyctial virus genotypes in five communities in North America. J Infect Dis. (2000) 181:1891-6. doi: $10.1086 / 315508$

27. Peret TCT, Hall CB, Schnable KC, Golum JA, Anderson LJ. Circulation patterns of genetically distinct group A and B strains of human respiratory syncytial virus in a community. J Gen Virol. (1998) 79:2221-9. doi: 10.1099/0022-1317-79-9-2221

28. Connors M, Collins PL, Firestone C-Y, Murphy BR. Respiratory syncytial virus (RSV) F, G, M2 (22K), and N proteins each induce resistance to RSV Challenge, but resistance induced by M2 and N proteins is relatively short-lived. Virol J. (1991) 65:1634-7.

29. Anderson LJ. Respiratory syncytial virus vaccine development. Semin Immunol. (2013) 25:160-71. doi: 10.1016/j.smim.2013.04.011

30. Collins PL, Murphy BR. New generation live vaccines against human respiratory syncytial virus designed by reverse genetics. Proc Am Thorac Soc. (2005) 2:166-73. doi: 10.1513/pats.200501-011AW

31. Collins PL, Whitehead SS, Bukreyev A, Fearns R, Teng MN, Juhasz K, et al. Rational design of live-attenuated recombinant vaccine virus for human respiratory syncytial virus by reverse genetics. Adv Virus Res. (1999) 54:42351. doi: 10.1016/S0065-3527(08)60374-7

32. PATH, RSV Vaccine Landscape.

33. Buchholz UJ, Cunningham CK, Muresan P, Gnanashanmugam D, Sato P, Siberry GK, et al. International maternal pediatric adolescent, live respiratory syncytial virus (RSV) vaccine candidate containing stabilized temperature-sensitivity mutations is highly attenuated in RSV-seronegative infants and children. J Infect Dis. (2018) 217:1338-46. doi: 10.1093/infdis/ jiy066

34. McFarland EJ, Karron RA, Muresan P, Cunningham CK, Valentine ME, Perlowski C, et al. International maternal pediatric adolescent, liveattenuated respiratory syncytial virus vaccine candidate with deletion of RNA synthesis regulatory protein M2-2 is highly immunogenic in children. J Infect Dis. (2018) 217:1347-55. doi: 10.1093/infdis/jiy040

35. Bernstein DI, Falloon J, Yi T. A randomized, double-blind, placebocontrolled, phase $1 / 2$ a study of the safety and immunogenicity of a live, attenuated human parainfluenza virus type 3 vaccine in healthy infants. Vaccine. (2011) 29:7042-8. doi: 10.1016/j.vaccine.2011. 07.031

36. Le Nouen C, Brock LG, Luongo C, McCarty T, Yang L, Mehedi M, et al. Attenuation of human respiratory syncytial virus by genome-scale codon-pair deoptimization. Proc Natl Acad Sci USA. (2014) 111:13169-74. doi: 10.1073/pnas.1411290111

37. Meng J, Lee S, Hotard AL, Moore ML. Refining the balance of attenuation and immunogenicity of respiratory syncytial virus by targeted codon deoptimization of virulence genes. mBio. (2014) 5:e01704-14. doi: 10.1128/mBio.01704-14
38. Aranda SS, Polack FP. Prevention of pediatric respiratory syncytial virus lower respiratory tract illness: perspectives for the next decade. Front Immunol. (2019) 10:1006. doi: 10.3389/fimmu.2019.01006

39. Villafana T, Falloon J, Griffin MP, Zhu Q, Esser MT. Passive and active immunization against respiratory syncytial virus for the young and old. Expert Rev Vaccines. (2017) 16:1-13. doi: 10.1080/14760584.2017.1333425

40. Whelan JN, Tran KC, van Rossum DB, Teng MN. Identification of respiratory syncytial virus nonstructural protein 2 residues essential for exploitation of the host ubiquitin system and inhibition of innate immune responses. J Virol. (2016) 90:6453-63. doi: 10.1128/JVI.00423-16

41. Munir S, Hillyer P, Le Nouen C, Buchholz UJ, Rabin RL, Collins PL, et al. Respiratory syncytial virus interferon antagonist NS1 protein suppresses and skews the human T lymphocyte response. PLoS Pathog. (2011) 7:e1001336. doi: 10.1371/journal.ppat.1001336

42. Munir S, Le Nouen C, Luongo C, Buchholz UJ, Collins PL, Bukreyev A. Nonstructural proteins 1 and 2 of respiratory syncytial virus suppress maturation of human dendritic cells. J Virol. (2008) 82:8780-96. doi: 10.1128/JVI.00630-08

43. Le Nouen C, Munir S, Losq S, Winter CC, McCarty T, Stephany DA, et al. Infection and maturation of monocyte-derived human dendritic cells by human respiratory syncytial virus, human metapneumovirus, and human parainfluenza virus type 3. Virology. (2009) 385:169-82. doi: 10.1016/j.virol.2008.11.043

44. Chatterjee S, Luthra P, Esaulova E, Agapov E, Yen BC, Borek DM, et al. Structural basis for human respiratory syncytial virus NS1mediated modulation of host responses. Nat Microbiol. (2017) 2:17101. doi: 10.1038/nmicrobiol.2017.101

45. Spann KM, Tran KC, Chi B, Rabin RL, Collins PL. Suppression of the induction of alpha, beta, and lambda interferons by the NS1 and NS2 proteins of human respiratory syncytial virus in human epithelial cells and macrophages [corrected]. J Virol. (2004) 78:4363-9. doi: 10.1128/JVI.78.8.4363-4369.2004

46. Spann KM, Tran KC, Collins PL. Effects of nonstructural proteins NS1 and NS2 of human respiratory syncytial virus on interferon regulatory factor 3, NF-kappaB, and proinflammatory cytokines. J Virol. (2005) 79:5353-62. doi: 10.1128/JVI.79.9.5353-5362.2005

47. Boyapalle S, Wong T, Garay J, Teng M, San Juan-Vergara H, Mohapatra S, H. Respiratory syncytial virus NS1 protein colocalizes with mitochondrial antiviral signaling protein MAVS following infection. PLOS ONE. (2012) 7:e29386. doi: 10.1371/journal.pone.0029386

48. Ren J, Liu T, Pang L, Li K, Garofalo RP, Casola A, H. A novel mechanism for the inhibition of interferon regulatory factor-3-dependent gene expression by human respiratory syncytial virus NS1 protein. J Gen Virol. (2011) 92:2153-9. doi: 10.1099/vir.0.032987-0

49. Ling Z, Tran KC, Teng MN. Human respiratory syncytial virus nonstructural protein NS2 antagonizes the activation of beta interferon transcription by interacting with RIG-I. J Virol. (2009) 83:3734-42. doi: 10.1128/JVI.02434-08

50. Teng MN, Whitehead SS, Bermingham A, St. Claire M, Elkins WR, Murphy $\mathrm{BR}, \mathrm{H}$. Recombinant respiratory syncytial virus that does not express the NS1 or M2-2 protein is highly attenuated and immunogenic in chimpanzees. $J$ Virol. (2000) 74:9317-21. doi: 10.1128/JVI.74.19.9317-9321.2000

51. Jin H, Cheng X, Traina-Dorge VL, Park HJ, Zhou H, et al. Evaluation of recombinant respiratory syncytial virus gene deletion mutants in African green monkeys for their potential as live attenuated vaccine candidates. Vaccine. (2003) 21:3647-52. doi: 10.1016/S0264-410X(03)00426-2

52. Schlender J, Bossert B, Buchholz U, Conzelmann KK. Bovine respiratory syncytial virus nonstructural proteins NS1 and NS2 cooperatively antagonize alpha/beta interferon-induced antiviral response. J Virol. (2000) 74:8234-42. doi: 10.1128/JVI.74.18.8234-8242.2000

53. Whitehead SS, Bukreyev A, Teng MN, Firestone CY, St. Claire M, Elkins WR, et al. Recombinant respiratory syncytial virus bearing a deletion of either the NS2 or SH gene is attenuated in chimpanzees. J Virol. (1999) 73:3438-42.

54. Valarcher JF, Furze J, Wyld SG, Cook R, Zimmer G, Herrler G, et al. Bovine respiratory syncytial virus lacking the virokinin or with a mutation in furin cleavage site RA(R/K)R109 induces less pulmonary inflammation without impeding the induction of protective immunity in calves. J Gen Virol. (2006) 87:1659-67. doi: 10.1099/vir.0.81755-0 
55. Valarcher JF, Furze J, Wyld S, Cook R, Conzelmann KK, Taylor G. Role of alpha/beta interferons in the attenuation and immunogenicity of recombinant bovine respiratory syncytial viruses lacking NS proteins. J Virol. (2003) 77:8426-39. doi: 10.1128/JVI.77.15.8426-8439.2003

56. Bakker SE, Duquerroy S, Galloux M, Loney C, Conner E, Eleouet JF, et al. The respiratory syncytial virus nucleoprotein-RNA complex forms a left-handed helical nucleocapsid. J Gen Virol. (2013) 94:1734-8. doi: 10.1099/vir.0.053025-0

57. Tawar RG, Duquerroy S, Vonrhein C, Varela PF, Damier-Piolle L, Castagne N, et al. Crystal structure of a nucleocapsid-like nucleoproteinRNA complex of respiratory syncytial virus. Science. (2009) 326:1279-83. doi: 10.1126/science.1177634

58. Groskreutz DJ, Babor EC, Monick MM, Varga SM, Hunninghake GW. Respiratory syncytial virus limits alpha subunit of eukaryotic translation initiation factor 2 (eIF2alpha) phosphorylation to maintain translation and viral replication. J Biol Chem. (2010) 285:24023-31. doi: 10.1074/jbc.M109.077321

59. Cespedes PF, Bueno SM, Ramirez BA, Gomez RS, Riquelme SA, Palavecino CE, et al. Surface expression of the hRSV nucleoprotein impairs immunological synapse formation with T cells. Proc Natl Acad Sci USA. (2014) 111:E3214-23. doi: 10.1073/pnas.1400760111

60. Herve PL, Descamps D, Deloizy C, Dhelft V, Laubreton D, Bouguyon E, et al. Non-invasive epicutaneous vaccine against Respiratory Syncytial Virus: preclinical proof of concept. J Control Release. (2016) 243:146-59. doi: 10.1016/j.jconrel.2016.10.003

61. Roux X, Dubuquoy C, Durand G, Tran-Tolla TL, Castagne N, Bernard J, et al. Sub-nucleocapsid nanoparticles: a nasal vaccine against respiratory syncytial virus. PLoS ONE. (2008) 3:e1766. doi: 10.1371/journal.pone.0001766

62. Esperante SA, Paris G, de Prat-Gay G. Modular unfolding and dissociation of the human respiratory syncytial virus phosphoprotein $\mathrm{p}$ and its interaction with the $\mathrm{m}(2-1)$ antiterminator: a singular tetramer-tetramer interface arrangement. Biochemistry. (2012) 51:8100-10. doi: 10.1021/bi300765c

63. Meshram CD, Baviskar PS, Ognibene CM, Oomens AGP. The respiratory syncytial virus phosphoprotein, matrix protein, and fusion protein carboxyterminal domain drive efficient filamentous virus-like particle formation. $J$ Virol. (2016) 90:10612-28. doi: 10.1128/JVI.01193-16

64. Ghildyal R, Ho A, Jans DA. Central role of the respiratory syncytial virus matrix protein in infection. FEMS Microbiol Rev. (2006) 30:692-705. doi: 10.1111/j.1574-6976.2006.00025.x

65. Henderson G, Murray J, Yeo RP. Sorting of the respiratory syncytial virus matrix protein into detergent-resistant structures is dependent on cell-surface expression of the glycoproteins. Virology. (2002) 300:244-54. doi: 10.1006/viro.2002.1540

66. Teng MN, Collins PL. Identification of the respiratory syncytial virus proteins required for formation and passage of helper-dependent infectious particles. J Virol. (1998) 72:5707-16.

67. Ke Z, Dillard RS, Chirkova T, Leon F, Stobart CC, Hampton CM, et al. The morphology and assembly of respiratory syncytial virus revealed by cryo-electron tomography. Viruses. (2018) 10:1-22. doi: 10.3390/ v10080446

68. Liljeroos L, Krzyzaniak MA, Helenius A, Butcher SJ. Architecture of respiratory syncytial virus revealed by electron cryotomography. Proc Natl Acad Sci USA. (2013) 110:11133-8. doi: 10.1073/pnas.13090 70110

69. Mitra R, Baviskar P, Duncan-Decocq RR, Patel D, Oomens AG. The human respiratory syncytial virus matrix protein is required for maturation of viral filaments. J Virol. (2012) 86:4432-43. doi: 10.1128/JVI.06744-11

70. Schwarz B, Morabito KM, Ruckwardt TJ, Patterson DP, Avera J, Miettinen $\mathrm{HM}$, et al. Viruslike particles encapsidating respiratory syncytial virus $\mathrm{M}$ and M2 proteins induce robust T cell responses. ACS Biomater Sci Eng. (2016) 2:2324-32. doi: 10.1021/acsbiomaterials.6b00532

71. Roumanes D, Falsey AR, Quataert S, Secor-Socha S, Lee FE, Yang H, et al. T-cell responses in adults during natural respiratory syncytial virus infection. J Infect Dis. (2018) 218:418-28. doi: 10.1093/infdis/ jiy016

72. Gan SW, Tan E, Lin X, Yu D, Wang J, Tan GM, et al. The small hydrophobic protein of the human respiratory syncytial virus forms pentameric ion channels. J Biol Chem. (2012) 287:24671-89. doi: 10.1074/jbc.M111.332791
73. Triantafilou K, Kar S, Vakakis E, Kotecha S, Triantafilou M. Human respiratory syncytial virus viroporin $\mathrm{SH}$ : a viral recognition pathway used by the host to signal inflammasome activation. Thorax. (2013) 68:66-75. doi: 10.1136/thoraxjnl-2012-202182

74. Karron RA, Buonagurio DA, Georgiu AF, Whitehead SS, Adamus JE, Clements-Mann ML, et al. Respiratory syncytial virus (RSV) $\mathrm{SH}$ and $\mathrm{G}$ proteins are not essential for viral replication in vitro: clinical evaluation and molecular characterization of a cold-passaged, attenuated RSV subgroup B mutant. Proc Natl Acad Sci USA. (1997) 94:13961-6. doi: 10.1073/pnas.94.25.13961

75. Stobart CC, Rostad CA, Ke Z, Dillard RS, Hampton CM, Strauss JD, et al. A live RSV vaccine with engineered thermostability is immunogenic in cotton rats despite high attenuation. Nat Commun. (2016) 7:13916. doi: $10.1038 /$ ncomms 13916

76. Akerlind-Stopner B, Hu A, Mufson MA, Utter G, Norrby E. Antibody responses of children to the C-terminal peptide of the $\mathrm{SH}$ protein of respiratory syncytial virus and the immunological characterization of this protein. J Med Virol. (1993) 40:112-20. doi: 10.1002/jmv.1890400207

77. Schepens B, Sedeyn K, Vande Ginste L, De Baets S, Schotsaert M, Roose K, et al. Protection and mechanism of action of a novel human respiratory syncytial virus vaccine candidate based on the extracellular domain of small hydrophobic protein. EMBO Mol Med. (2014) 6:1436-54. doi: 10.15252/emmm.201404005

78. Hagglund S, Hu K, Blodorn K, Makabi-Panzu B, Gaillard AL, Ellencrona $\mathrm{K}$, et al. Characterization of an experimental vaccine for bovine respiratory syncytial virus. Clin Vaccine Immunol. (2014) 21:997-1004. doi: 10.1128/CVI.00162-14

79. Tripp R, Jones L, Haynes L, Zheng H, Murphy P, Anderson L. CX3C chemokine mimicry by respiratory syncytial virus $\mathrm{G}$ protein. Nat Immunol. (2001) 2:732-8. doi: 10.1038/90675

80. Chirkova T, Lin S, Oomens AG, Gaston KA, Boyoglu-Barnum S, Meng J, et al. CX3CR1 is an important surface molecule for respiratory syncytial virus infection in human airway epithelial cells. J Gen Virol. (2015) 96:2543-56. doi: 10.1099/vir.0.000218

81. Jeong KI, Piepenhagen PA, Kishko M, DiNapoli JM, Groppo RP, Zhang L, et al. CX3CR1 is expressed in differentiated human ciliated airway cells and co-localizes with respiratory syncytial virus on cilia in a $G$ protein-dependent manner. PLoS ONE. (2015) 10:e0130517. doi: 10.1371/journal.pone. 0130517

82. Johnson SM, McNally BA, Ioannidis I, Flano E, Teng MN, Oomens AG, et al. Respiratory syncytial virus uses CX3CR1 as a receptor on primary human airway epithelial cultures. PLoS Pathog. (2015) 11:e1005318. doi: 10.1371/journal.ppat.1005318

83. Harrison JK, Jiang Y, Chen S, Xia Y, Maciejewski D, McNamara RK, et al. Role for neuronally derived fractalkine in mediating interactions between neurons and CX3CR1-expressing microglia. Proc Natl Acad Sci USA. (1998) 95:10896-901. doi: 10.1073/pnas.95.18.10896

84. Perros F, Dorfmuller P, Souza R, Durand-Gasselin I, Godot V, Capel F, et al. Fractalkine-induced smooth muscle cell proliferation in pulmonary hypertension. Eur Respir J. (2007) 29:937-43. doi: 10.1183/09031936.00104706

85. Nishimura $M$, Umehara $H$, Nakayama $T$, Yoneda O, Hieshima $K$, Kakizaki $M$, et al. Dual functions of fractalkine/CX3C ligand 1 in trafficking of perforin+/granzyme B+ cytotoxic effector lymphocytes that are defined by CX3CR1 expression. J Immunol. (2002) 168:6173-80. doi: 10.4049/jimmunol.168.12.6173

86. Bar-On L, Birnberg T, Lewis KL, Edelson BT, Bruder D, Hildner K, et al. CX3CR1+ CD8alpha+ dendritic cells are a steady-state population related to plasmacytoid dendritic cells. Proc Natl Acad Sci USA. (2010) 107:1474550. doi: 10.1073/pnas.1001562107

87. Corcione A, Ferretti E, Bertolotto M, Fais F, Raffaghello L, Gregorio A, et al. CX3CR1 is expressed by human B lymphocytes and mediates [corrected] CX3CL1 driven chemotaxis of tonsil centrocytes. PLoS ONE. (2009) 4:e8485. doi: 10.1371/journal.pone.0008485

88. Tripp RA, Dakhama A, Jones LP, Barskey A, Gelfand EW, Anderson LJ. Respiratory syncytial virus depressses respiratory rates through the G glycoprotein CX3C motif and substance Virol P J. (2003) 77:6580-4. doi: 10.1128/JVI.77.11.6580-6584.2003 
89. Harcourt J, Alvarez R, Jones LP, Henderson C, Anderson LJ, Tripp RA. Respiratory syncytial virus $G$ protein and $G$ protein $\mathrm{CX} 3 \mathrm{C}$ motif adversely affect CX3CR1+ T cell responses. J Immunol. (2006) 176:1600-8. doi: 10.4049/jimmunol.176.3.1600

90. Haynes LM, Jones LP, Barskey A, Anderson LJ, Tripp RA. Enhanced disease and pulmonary eosinophilia associated with formalin-inactivated respiratory syncytial virus vaccination are linked to $\mathrm{G}$ glycoprotein CX3C-CX3CR1 interaction and expression of substance P. J Virol. (2003) 77:9831-44. doi: 10.1128/JVI.77.18.9831-9844.2003

91. Boyoglu-Barnum S, Chirkova T, Todd SO, Barnum TR, Gaston KA, Jorquera $\mathrm{P}$, et al. Prophylaxis with a respiratory syncytial virus (RSV) anti-G protein monoclonal antibody shifts the adaptive immune response to RSV rA2line19F infection from Th2 to Th1 in BALB/c mice. J Virol. (2014) 88:1056983. doi: 10.1128/JVI.01503-14

92. Chirkova T, Boyoglu-Barnum S, Gaston KA, Malik FM, Trau SP, Oomens AG, et al. Respiratory syncytial virus $\mathrm{G}$ protein CX3C motif impairs human airway epithelial and immune cell responses. J Virol. (2013) 87:13466-79. doi: 10.1128/JVI.01741-13

93. Zhivaki D, Lemoine S, Lim A, Morva A, Vidalain PO, Schandene L, et al. Respiratory syncytial virus infects regulatory B cells in human neonates via chemokine receptor CX3CR1 and promotes lung disease severity. Immunity. (2017) 46:301-14. doi: 10.1016/j.immuni.2017.01.010

94. Haynes LM, Caidi H, Radu GU, Miao C, Harcourt JL, Tripp RA, et al. Therapeutic monoclonal antibody treatment targeting respiratory syncytial virus (RSV) G protein mediates viral clearance and reduces the pathogenesis of RSV infection in BALB/c mice. J Infect Dis. (2009) 200:439-47. doi: $10.1086 / 600108$

95. Miao C, Radu GU, Caidi H, Tripp RA, Anderson LJ, Haynes LM. Treatment with respiratory syncytial virus $G$ glycoprotein monoclonal antibody or $\mathrm{F}\left(\mathrm{ab}^{\prime}\right) 2$ components mediates reduced pulmonary inflammation in mice. $J$ Gen Virol. (2009) 90:1119-23. doi: 10.1099/vir.0.009308-0

96. Boyoglu-Barnum S, Gaston KA, Todd SO, Boyoglu C, Chirkova T, Barnum TR, et al. A respiratory syncytial virus (RSV) anti-G protein $F(a b$ ')2 monoclonal antibody suppresses mucous production and breathing effort in RSV rA2-line19F-infected BALB/c mice. J Virol. (2013) 87:10955-67. doi: 10.1128/JVI.01164-13

97. Boyoglu-Barnum S, Todd SO, Chirkova T, Barnum TR, Gaston KA, Haynes LM, et al. An anti-G protein monoclonal antibody treats RSV disease more effectively than an anti-F monoclonal antibody in BALB/c mice. Virology. (2015) 483:117-25. doi: 10.1016/j.virol.2015.02.035

98. Radu GU, Caidi H, Miao C, Tripp RA, Anderson LJ, Haynes LM. Prophylactic treatment with a $\mathrm{G}$ glycoprotein monoclonal antibody reduces pulmonary inflammation in respiratory syncytial virus (RSV)-challenged naive and formalin-inactivated RSV-immunized BALB/c mice. J Virol. (2010) 84:9632-6. doi: 10.1128/JVI.00451-10

99. Rey GU, Miao C, Caidi H, Trivedi SU, Harcourt JL, Tripp RA, et al. Decrease in formalin-inactivated respiratory syncytial virus (FI-RSV) enhanced disease with RSV G glycoprotein peptide immunization in BALB/c mice. PLoS ONE. (2013) 8:e83075. doi: 10.1371/journal.pone. 0083075

100. Boyoglu-Barnum S, Todd SO, Meng J, Barnum TR, Chirkova T, Haynes $\mathrm{LM}$, et al. Mutating the $\mathrm{CX} 3 \mathrm{C}$ motif in the $\mathrm{G}$ protein should make a live respiratory syncytial virus vaccine safer and more effective. J Virol. (2017) 91:e02059-16. doi: 10.1128/JVI.02059-16

101. Plotnicky-Gilquin H, Huss T, Aubry JP, Haeuw JF, Beck A, Bonnefoy JY, et al. Absence of lung immunopathology following respiratory syncytial virus (RSV) challenge in mice immunized with a recombinant RSV G protein fragment. Virology. (1999) 258:128-40. doi: 10.1006/viro.1999.9702

102. Zhang W, Choi Y, Haynes LM, Harcourt JL, Anderson LJ, Jones LP, et al. Vaccination to induce antibodies blocking the CX3C-CX3CR1 interaction of respiratory syncytial virus $G$ protein reduces pulmonary inflammation and virus replication in mice. J Virol. (2010) 84:1148-57. doi: 10.1128/JVI.01755-09

103. Jorquera PA, Choi Y, Oakley KE, Powell TJ, Boyd JG, Palath N, et al. Nanoparticle vaccines encompassing the respiratory syncytial virus (RSV) G protein CX3C chemokine motif induce robust immunity protecting from challenge and disease. PLoS ONE. (2013) 8:e74905. doi: 10.1371/journal.pone. 0074905
104. Quan FS, Kim Y, Lee S, Yi H, Kang SM, Bozja J, et al. Viruslike particle vaccine induces protection against respiratory syncytial virus infection in mice. $J$ Infect Dis. (2011) 204:987-95. doi: 10.1093/infdis/jir474

105. Lee J, Klenow L, Coyle EM, Golding H, Khurana S. Protective antigenic sites in respiratory syncytial virus $\mathrm{G}$ attachment protein outside the central conserved and cysteine noose domains. PLoS Pathog. (2018) 14:e1007262. doi: 10.1371/journal.ppat.1007262

106. McGinnes LW, Gravel KA, Finberg RW, Kurt-Jones EA, Massare MJ, Smith $\mathrm{G}$, et al. Assembly and immunological properties of Newcastle disease viruslike particles containing the respiratory syncytial virus $\mathrm{F}$ and $\mathrm{G}$ proteins. $J$ Virol. (2011) 85:366-77. doi: 10.1128/JVI.01861-10

107. Lee YN, Suk Hwang H, Kim MC, Lee YT, Cho MK, Kwon YM, et al. Recombinant influenza virus carrying the conserved domain of respiratory syncytial virus (RSV) G protein confers protection against RSV without inflammatory disease. Virology. (2015) 476:217-225. doi: 10.1016/j.virol.2014.12.004

108. Nguyen TN, Power UF, Robert A, Haeuw JF, Helffer K, Perez A, et al. The respiratory syncytial virus $G$ protein conserved domain induces a persistent and protective antibody response in rodents. PLoS ONE. (2012) 7:e34331. doi: 10.1371/journal.pone.0034331

109. Power UF, Nguyen TN, Rietveld E, de Swart RL, Groen J, Osterhaus AD, et al. Safety and immunogenicity of a novel recombinant subunit respiratory syncytial virus vaccine (BBG2Na) in healthy young adults. J Infect Dis. (2001) 184:1456-60. doi: 10.1086/324426

110. Graham BS, Modjarrad K, McLellan JS. Novel antigens for RSV vaccines. Curr Opin Immunol. (2015) 35:30-8. doi: 10.1016/j.coi.2015.04.005

111. Zhao X, Singh M, Malashkevich VN, Kim PS. Structural characterization of the human respiratory syncytial virus fusion protein core. Proc Natl Acad Sci USA. (2000) 97:14172-7. doi: 10.1073/pnas.260499197

112. Johnson PR Jr, Olmsted RA, Prince GA, Murphy BR, Alling DW, Walsh EE, et al. Antigenic relatedness between glycoproteins of human respiratory syncytial virus subgroups A and B: evaluation of the contributions of $F$ and G glycoproteins to immunity. J Virol. (1987) 61:3163-6.

113. Feldman SA, Audet S, Beeler JA. The fusion glycoprotein of human respiratory syncytial virus facilitates virus attachment and infectivity via an interaction with cellular heparan sulfate. J Virol. (2000) 74:6442-7. doi: 10.1128/JVI.74.14.6442-6447.2000

114. Tayyari F, Marchant D, Moraes TJ, Duan W, Mastrangelo P, Hegele RG. Identification of nucleolin as a cellular receptor for human respiratory syncytial virus. Nat Med. (2011) 17:1132-5. doi: 10.1038/nm.2444

115. Currier MG, Lee S, Stobart CC, Hotard AL, Villenave R, Meng J, et al. EGFR interacts with the fusion protein of respiratory syncytial virus strain 2-20 and mediates infection and mucin expression. PLoS Pathog. (2016) 12:e1005622. doi: 10.1371/journal.ppat.1005622

116. Mousa JJ, Kose N, Matta P, Gilchuk P, Crowe JE Jr. A novel prefusion conformation-specific neutralizing epitope on the respiratory syncytial virus fusion protein. Nat Microbiol. (2017) 2:16271. doi: 10.1038/nmicrobiol.2016.271

117. Krarup A, Truan D, Furmanova-Hollenstein P, Bogaert L, Bouchier P, Bisschop IJ, et al. A highly stable prefusion RSV F vaccine derived from structural analysis of the fusion mechanism. Nat Commun. (2015) 6:8143. doi: $10.1038 /$ ncomms 9143

118. Ngwuta JO, Chen M, Modjarrad K, Joyce MG, Kanekiyo M, Kumar A, et al. Prefusion F-specific antibodies determine the magnitude of RSV neutralizing activity in human sera. Sci Transl Med. (2015) 7:309ra162. doi: 10.1126/scitranslmed.aac4241

119. Magro M, Mas V, Chappell K, Vazquez M, Cano O, Luque D, et al. Neutralizing antibodies against the preactive form of respiratory syncytial virus fusion protein offer unique possibilities for clinical intervention. Proc Natl Acad Sci USA. (2012) 109:3089-94. doi: 10.1073/pnas. 1115941109

120. McLellan JS, Chen M, Joyce MG, Sastry M, Stewart-Jones GB, Yang Y, et al. Structure-based design of a fusion glycoprotein vaccine for respiratory syncytial virus. Science. (2013) 342:592-8. doi: 10.1126/science.1243283

121. van Mechelen L, Luytjes W, de Haan CA, Wicht O. RSV neutralization by palivizumab, but not by monoclonal antibodies targeting other epitopes, is augmented by Fc gamma receptors. Antiviral Res. (2016) 132:1-5. doi: $10.1016 /$ j.antiviral.2016.05.003 
122. Hiatt A, Bohorova N, Bohorov O, Goodman C, Kim D, Pauly MH, et al. Glycan variants of a respiratory syncytial virus antibody with enhanced effector function and in vivo efficacy. Proc Natl Acad Sci USA. (2014) 111:5992-7. doi: 10.1073/pnas.1402458111

123. Melero JA, Mas V, McLellan JS. Structural, antigenic and immunogenic features of respiratory syncytial virus glycoproteins relevant for vaccine development. Vaccine. (2017) 35:461-468. doi: 10.1016/j.vaccine.2016.09.045

124. Hotard AL, Lee S, Currier MG, Crowe JE Jr, Sakamoto K, Newcomb DC, et al. Identification of residues in the human respiratory syncytial virus fusion protein that modulate fusion activity and pathogenesis. J Virol. (2015) 89:512-22. doi: 10.1128/JVI.02472-14

125. Rostad CA, Stobart CC, Todd SO, Molina SA, Lee S, Blanco JCG, et al. Enhancing the thermostability and immunogenicity of a Respiratory Syncytial Virus (RSV) live-attenuated vaccine by incorporating unique RSV line19F protein residues. J Virol. (2018) 92:e01568-17. doi: 10.1128/JVI.01568-17

126. Bermingham A, Collins PL. The M2-2 protein of human respiratory syncytial virus is a regulatory factor involved in the balance between RNA replication and transcription. Proc Natl Acad Sci USA. (1999) 96:11259-64. doi: 10.1073/pnas.96.20.11259

127. Fearns R, Collins PL. Role of the M2-1 transcription antitermination protein of respiratory syncytial virus in sequential transcription. $J$ Virol. (1999) 73:5852-64.

128. Hardy RW, Harmon SB, Wertz GW. Diverse gene junctions of respiratory syncytial virus modulate the efficiency of transcription termination and respond differently to M2-mediated antitermination. $J$ Virol. (1999) 73:170-6.

129. Tanner SJ, Ariza A, Richard CA, Kyle HF, Dods RL, Blondot ML, et al. Crystal structure of the essential transcription antiterminator M2-1 protein of human respiratory syncytial virus and implications of its phosphorylation. Proc Natl Acad Sci USA. (2014) 111:1580-5. doi: 10.1073/pnas.1317 262111

130. Kiss G, Holl JM, Williams GM, Alonas E, Vanover D, Lifland AW, et al. Structural analysis of respiratory syncytial virus reveals the position of M21 between the matrix protein and the ribonucleoprotein complex. J Virol. (2014) 88:7602-17. doi: 10.1128/JVI.00256-14
131. Green CA, Scarselli E, Sande CJ, Thompson AJ, de Lara CM, Taylor KS, et al. Chimpanzee adenovirus- and MVA-vectored respiratory syncytial virus vaccine is safe and immunogenic in adults. Sci Transl Med. (2015) 7:300ra126. doi: 10.1126/scitranslmed.aac5745

132. Collins PL, Hill MG, Johnson PR. The two open reading frames of the $22 \mathrm{~K}$ mRNA of human respiratory syncytial virus: sequence comparison of antigenic subgroups A and B and expression in vitro. J Gen Virol. (Pt 12) (1990) 71:3015-20. doi: 10.1099/0022-1317-71-12-3015

133. Karron RA, Luongo C, Thumar B, Loehr KM, Englund JA, Collins PL, et al. A gene deletion that up-regulates viral gene expression yields an attenuated RSV vaccine with improved antibody responses in children. Sci Transl Med. (2015) 7:312ra175. doi: 10.1126/scitranslmed.aac8463

134. Morin B, Kranzusch PJ, Rahmeh AA, Whelan SP. The polymerase of negative-stranded RNA viruses. Curr Opin Virol. (2013) 3:103-10. doi: 10.1016/j.coviro.2013.03.008

Conflict of Interest Statement: LA has done paid consultancies on RSV vaccines for Moderna Therapeutics, Inc., Bavarian Nordic, Novavax, Daiichi-Sankyo, and ClearPath Vaccines Company. LA's laboratory is receiving funding through Emory University from Pfizer for RSV surveillance studies in adults. LA is a co-inventor on several CDC patents on the RSV G protein and its CX3C Q10 chemokine motif relative to immune therapy and vaccine development. LA is also a co-inventor on an Emory patent filing for use of RSV platform VLPs with the F and G proteins for vaccines.

The remaining authors declare that the research was conducted in the absence of any commercial or financial relationships that could be construed as a potential conflict of interest.

Copyright (C) 2019 Boyoglu-Barnum, Chirkova and Anderson. This is an open-access article distributed under the terms of the Creative Commons Attribution License (CC $B Y)$. The use, distribution or reproduction in other forums is permitted, provided the original author(s) and the copyright owner(s) are credited and that the original publication in this journal is cited, in accordance with accepted academic practice. No use, distribution or reproduction is permitted which does not comply with these terms. 